\title{
PERJANJIAN BAGI HASIL \\ DALAM PEMBIAYAAN SYARIAH YANG BERKEADILAN SEBAGAI SALAH SATU UPAYA PENGEMBANGAN BANK SYARIAH
}

\author{
Renny Supriyatni Bachro \\ Fakultas Hukum Universitas Padjadjaran \\ JII. Dipati Ukur No. 35 Bandung 40132
}

\begin{abstract}
ABSTRAK. Perwujudan dual banking system di Indonesia, telah dipelopori dengan berdirinya sebuah Bank Umum berdasarkan prinsip Syariah yaitu Bank Muamalat Indonesia (BMI). Fenomena rendahnya pembiayaan dengan sistem bagi hasil merupakan permasalahan menarik dan penting yang perlu dibahas dan diteliti, diantaranya penerapan sistem bagi hasil dalam perjanjian pembiayaan Syariah yang tidak menggunakan mekanisme pembagian untung dan rugi (profit and loss sharing) terhadap pengembangan bank syariah; akibat hukum kebijakan Peraturan Bank Indonesia (PBI) terhadap pengembangan Bank Syariah; dan konsep pembiayaan syariah yang dapat memberi rasa keadilan bagi bank dan nasabah dalam pengembangan sistem perbankan Indonesia. Penelitian ini bersifat deskriptif analisis dengan metode pendekatan yang dilakukan adalah yuridis normatif. Dalam arti meneliti, dan mengkaji bahan pustaka (obyek) tersebut melalui sumber hukumnya yang menyangkut perundang-undangan mengenai sistem Bagi Hasil. Untuk mempertajam analisis maka diperlukan studi perbandingan hukum (comparative study). Selanjutnya data yang diperoleh dari hasil penelitian, akan dianalisis secara yuridis kualitatif. Hasil penelitian yang diperoleh, pertama, akad/perjanjian bagi hasil dengan mekanisme bagi pendapatan (revenue sharing mechanism) memiliki tingkat ketidakpastian/risiko yang lebih rendah dibandingkan dengan akad/perjanjian dengan mekanisme bagi untung dan rugi (profit and loss sharing), dan pemilik dana hanya mengalami kerugian sampai sebatas modalnya. Kedua, kebijakan yang dikeluarkan oleh Bank Indonesia (BI) berupa Peraturan Bank Indonesia (PBI) tidak cukup untuk mempercepat perkembangan bank syariah di Indonesia. Ketiga, konsep bagi hasil dalam perjanjian pembiayaan syariah yang menggunakan mekanisme bagi untung dan bagi rugi (profit and Loss sharing mechanism) karena mengandung dimensi keadilan distributif dan hubungan kemitraan usaha yang bersifat kesetaraan. Saran yang dapat dikemukakan, rendahnya pembiayaan dengan sistem bagi hasil seyogyanya dilihat secara proporsional oleh semua stakeholders, termasuk regulator dalam mengeluarkan kebijakan, dengan memperhatikan semua aspek yang terkait. Peningkatan kualitas dan kuantitas Sumber Daya Insani/Islami dapat dilakukan secara berjenjang, dan berkesinambungan secara berkala untuk jangka pendek dan jangka panjang.
\end{abstract}

Kata Kunci: Perjanjian, Bagi Hasil, Pembiayaan Syariah, Berkeadilan, dan Bank Syariah. 


\title{
PROFIT SHARING CONTRACT UNDER EQUITABLE SYARIAH FUNDING AS AN EFFORT TO DEVELOP SYARIAH BANKING
}

\begin{abstract}
The result of dual banking system in Indonesia has been pioneered by the establishment of a general Bank based on the principal of Syariah, Bank Muamalat Indonesia (BMI). The phenomenon of low financing with sharing profit system is an interesting affair and important to discuss and examine, they are the acknowledging sharing system in financing syariah agreement that is not using the mechanism of profit and loss sharing upon the development of Syariah Bank; and concept financing syariah that is able in giving the fairness for both the Bank and the costumer to develop the banking system in Indonesia. The research is descriptive analytical one with juridical normative approach in the mean of researching, and studying the bibliography (object) through its sole source that contains constitutions about profit sharing. To sharpen the analyses in order, thus the comparative study of law is needed that is done. The data that is gathered from library, and is qualitatively analysed. The result that is gained are, first the agreement with the mechanism for the income (revenue sharing mechanism) has a low tendency of risk than the agreement with profit and loss sharing mechanism, and the money owner looses only the limit of his funds. Second, the judiciousness that is attempted by Indonesian Bank (BI) as regulation of Indonesian Bank (PBI) is not adequate to fasten the development of Syariah Bank. Third, the concept of sharing profit in agreement of financing syariah that employs the profit and loss sharing mechanism. Suggestion that can be found is the low point of financing with sharing profit system that is supposed to be seen proportionally by all the stakeholders, including regulator in attempting the judiciousness by taking carefully all aspects that are related to each other. The increasing quality and quantity of human resource can be done step by step, starting from the high position that balancing gradually for both short and long period.
\end{abstract}

Keywords: Contract, Profit Sharing, Syariah Funding, Equitable, and Syariah Banking.

\section{PENDAHULUAN}

Bank merupakan lembaga keuangan dan pembiayaan dimana setiap perusahaan maupun perorangan mempercayakan dana-dananya, dan melalui jasa bank pula arus barang dan jasa dapat terlaksana serta lalulintas pembayaran dapat berjalan lebih efisien. Dalam hal ini Bank memegang peranan yang sangat penting dalam pembangunan ekonomi dan merupakan pusat efektivitas kegiatan ekonomi (Hasan, 1996). Hal tersebut dipertegas dalam Penjelasan Atas Undang-undang Nomor 7 Tahun 1992 sebagaimana telah diubah dengan Undang-undang Nomor 10 Tahun 1998 Tentang Perbankan yang menyatakan : 
"Perbankan mempunyai peran strategis, terutama disebabkan dari fungsi utama bank sebagai suatu wahana yang dapat menghimpun dan menyalurkan dana masyarakat secara efektif dan efisien, yang dengan berasaskan demokrasi ekonomi mendukung pelaksanaan pembangunan nasional dalam rangka meningkatkan pemerataan pembangunan nasional dalam rangka meningkatkan pemerataan pembangunan dan hasil-hasilnya, pertumbuhan ekonomi dan stabilitas nasional ke arah peningkatan taraf hidup rakyat banyak "

Merupakan langkah maju dalam perkembangan perbankan, terutama bagi. Perbankan Islam (Is/amic Banking) atau lebih dikenal dengan istilah perbankan syariah yaitu bank yang dijalankan dengan didasarkan pada syariat Islam dan prinsip utamanya adalah larangan terhadap penarikan bunga dalam melakukan transaksi dan kegiatan bisnis serta perdagangan dengan pembagian keuntungan dan kerugian (lost and profit sharing principle) yang adil dan logis. Undang-undang Nomor 21 Tahun 2008 Tentang Perbankan Syariah, berlaku pada tanggal 16 Juli 2008 pada Lembaran Negara R.I. Tahun 2008 No. 94 dan TLN No. 4867 yang selanjutnya ditulis UUPS. Jaringan Kantor Perbankan Syariah digambarkan, sebagai berikut:

Tabel 1. Jaringan Kantor Perbankan di Indonesia dari Bulan Juni 2008 - April 2009

\begin{tabular}{lrrrrr} 
& \multicolumn{1}{c}{ Juni'08 } & Sept'08 & Des'08 & Maret'09 & April'09 \\
\hline BUS & 3 & 3 & 5 & 5 & 5 \\
Jumlah Bank & 405 & 497 & 581 & 635 & 642 \\
$\begin{array}{l}\text { Jumlah kantor } \\
\text { UUS }\end{array}$ & 28 & 28 & 27 & 26 & 25 \\
Jumlh BUK yg memiliki & 214 & 2167 & 241 & 253 & 253 \\
$\begin{array}{l}\text { UUS } \\
\text { Jumlah Kantor }\end{array}$ & 124 & 128 & 131 & 133 & 133 \\
$\begin{array}{l}\text { BPRS } \\
\text { Jumlah Bank }\end{array}$ & 195 & 199 & 202 & 208 & 209 \\
Jumlah kantor & & & & & \\
\hline Total Kantor & 814 & 912 & 1,024 & 1,096 & 1,104 \\
\hline
\end{tabular}

Sumber: Karim (2004) dan Tim Pengembangan Syariah IBI 2001

Dalam Undang-undang Perbankan itu sendiri, perbankan syariah mendapat perlakuan yang sama (equal treatment) dengan perbankan konvensional. Bahkan Undang-undang Nomor 3 Tahun 2004 Perubahan Atas Undang-undang Nomor 23 Tahun 1999 Tentang Bank Indonesia menugaskan kepada Bank Indonesia untuk mempersiapkan peraturan dan fasilitas penunjang yang mendukung operasional Bank Syariah, yaitu terselenggaranya dua sistem perbankan sekaligus (konvensional dan syariah) secara berdampingan dengan sistem administrasi jelas 
terpisah, yang selanjutnya penulis akan menggunakan istilah Bank Syariah. Padahal ketika undang-undang tersebut disahkan, baru ada satu bank syariah yaitu Bank Muamalat Indonesia (BMI). Bank Syariah menurut hukum positif Indonesia (sebelum UUPS terbentuk) dimungkinkan melalui Pasal 6 Huruf $(\mathrm{m})$ Undang-undang Nomor 7 Tahun 1992 sebagaimana telah diubah dengan Undangundang Nomor 10 Tahun 1998 Tentang Perbankan, yang memperbolehkan menyediakan pembiayaan dan atau melakukan kegiatan lain berdasarkan Prinsip Syariah.

Bagi Hasil (Profit and Loss Sharing) di Bank Syariah dapat dibedakan dengan Sistem Bunga (Interest) di Bank Konvensional dalam setiap transaksinya. Disamping itu prinsip bank syariah sangat memperhatikan asas kemaslahatan bagi orang banyak (Maslahah al-ammanah). Hal mendasar yang membedakan antara Bank Syariah dan Bank Konvensional adalah terletak pada pengembalian dan pembagian keuntungan yang diberikan oleh nasabah kepada bank dan/atau yang diberikan oleh bank kepada nasabah, sehingga terdapat istilah bunga dan bagi hasil. Untuk merealisasikan hal tersebut, sekarang pemerintah dan masyarakat khususnya yang beragama Islam telah mencoba mengembangkan paradigma perekonomian yang akan terus dikembangkan dalam rangka perbaikan ekonomi dan kesejahteraan umat. Caranya adalah berupa beroperasinya bank-bank syariah di Indonesia, dengan tidak mendasarkan pada bunga, namun dengan bagi hasil (Muhamad, 2004). Fenomena rendahnya pembiayaan dengan sistem bagi hasil merupakan permasalahan penting yang perlu dibahas dan diteliti. Apalagi adanya kecenderungan sebagian besar masyarakat beranggapan bahwa perbankan syariah tidak ada bedanya dengan perbankan konvensional, hanya merupakan pergantian nama saja sedangkan mind-set pelakunya tetaplah konvensional. Saat ini belum dapat dikatakan bagi bank syariah menerapkan secara murni apa yang terdapat dalam syariah Islam, bahkan adanya kecenderungan bank syariah seperti bank konvensional yang "disyariahkan" dalam segala operasionalnya, baik produknya maupun transaksinya.

Mengingat penyaluran dana dimaksud bersumber dari dana masyarakat yang disimpan pada Bank Syariah dan Unit Usaha Syariah (UUS), risiko yang dihadapi Bank Syariah dan Unit Usaha Syariah (UUS) dapat berpengaruh pula kepada keamanan dana masyarakat tersebut. Oleh karena itu, untuk memelihara kesehatan dan meningkatkan daya tahannya, bank diwajibkan menyebar risiko dengan mengatur penyaluran kredit atau pemberian pembiayaan berdasarkan Prinsip Syariah, pemberian jaminan ataupun fasilitas lain sedemikian rupa sehingga tidak terpusat pada Nasabah debitur atau kelompok Nasabah debitur tertentu. Disamping itu dalam melaksanakan program penyehatan, bank mempunyai wewenang untuk meninjau ulang, membatalkan, mengakhiri, dan/atau mengubah kontrak yang mengikat bank dengan pihak ketiga, yang menurut pertimbangan badan khusus merugikan bank. Oleh karena itu dalam menetapkan bagi hasil berdasarkan bagi pendapatan (revenue sharing) bagi bank sulit untuk membagi 
hasil/keuntungan berdasarkan prinsip bagi untung dan rugi (profit and loss sharing karena skala pembiayaan sangat kecil.

Permasalahan yang diteliti dirumuskan sebagai berikut:

1.Bagaimanakah penerapan sistem bagi hasil dalam perjanjian pembiayaan Syariah yang tidak menggunakan mekanisme pembagian untung dan rugi (profit and loss sharing) terhadap salah satu upaya pengembangan bank syariah?;

2.Bagaimanakah akibat hukum kebijakan Peraturan Bank Indonesia (PBI) dikaitkan dengan Undang-undang Perbankan Syariah terhadap pengembangan Bank Syariah?;

3. Bagaimanakah konsep pembiayaan syariah yang dapat memberi rasa keadilan bagi bank dan nasabah dalam pengembangan sistem perbankan Indonesia?.

\section{TINJAUAN PUSTAKA}

\section{Sistem Perbankan Indonesia}

Dalam Black's Law Dictionary:

"A bank is an institution, usually incorporated, whose business is it to receive money on deposit, cash checs or drafts, discount commercial paper, make loans, and issue promissory note payable to bearer, known as bank notes". (Cambell, 1991)

Kamus Besar Bahasa Indonesia mengartikan bank, adalah lembaga keuangan yang usaha pokoknya memberikan kredit dan jasa di lalu lintas pembayaran dan peredaran uang. Sementara itu, "Sistem Perbankan" terdiri dari dua kata, yaitu "Sistem" dan "Perbankan". Menurut Kamus Besar Bahasa Indonesia, kata "Sistem" memiliki 3 (tiga) arti, yaitu perangkat unsur yang secara teratur saling berkaitan sehingga membentuk suatu totalitas; susunan yang teratur dari pandangan, teori, asas, dsb; dan metode. Sedangkan, John M. Echols dan Hassan Shadily, dalam "Kamus Inggris Indonesia", menyatakan bahwa "sistem" adalah "susunan", "jaringan", dan "cara".

"Perbankan" adalah segala sesuatu yang menyangkut tentang Bank, mencakup kelembagaan, kegiatan usaha, serta cara dan proses dalam melaksanakan kegiatan usahanya. Black's Law Dictionary menyebutkan:

"The business of banking, as define by law and custom, consist in the issue of notes payable on demand intented to circulate as money when the banks are banks of issue; in receiving deposits payable on demand; in discounting commercial paper; making loans of money on collateral security; buying and selling bills of exchange; negotiating loans, and dealing and negotiable securities issued by the government, state and national, and municipal and other corporations". (Cambell, 1991) dan (Esposito, 2002) 


\section{Riba}

Asal makna Riba menurut Bahasa Arab ialah "lebih" (bertambah). "Riba" artinya suatu kontrak atas harta tertentu yang tidak diketahui persamaan dan ukurannya ketika akad dilaksanakan, atau melambatkan penyerahan barang yang dipertukarkan atau melambatkan salah satunya. Mengurut definisi ini, apabila terjadi pertukaran barang yang digolongkan kepada ribawi mestilah ukurannya sama, baik dari segi berat, bagi barang yang ditimbang, ataupun sukatannya, bagi barang yang disukat. Jadi apabila seseorang menukar satu gram emas dengan orang lain, maka ia harus menerima satu gram pula. Kalau terjadi kelebihan, maka itu dianggap sebagai barang riba. Riba diharamkan oleh agama Islam berdasakan ketentuan Al-Qur'an, Al-Hadist, dan bersifat qat'i, diantaranya firman Allah Swt., yang artinya: "Allah telah menghalalkan jual beli dan mengharamkan riba". (QS. alBaqarah [2] : 275) dan Hadist Rasulullah Saw. yang diriwayatkan dari Jabir, artinya:" Telah melaknati (mengutuki) Rasulullah Saw. kepada orang yang makan riba, wakilnya, penulisnya, dan dua saksinya." (Riwayat Muslim)

Berdasarkan definisi riba di atas, maka para pakar perundangan mazhab Syafi'i membagi riba atas empat jenis;

a. Riba al-Fadl, artinya tambahan (al-Ziyadah), yang dimaksudkan dengan riba jenis ini adalah jual beli harta ribawi dan sejenisnya dengan adanya tambahan yang dibuat oleh seorang yang berkontrak.

b. Riba an-Nasi'ah, artinya menangguhkan, yaitu ketka terjadi kontrak jual beli pada barang ribawi dengan barang ribawi yang sama atau berlainan, yang waktu pembayarannya ditangguhkan, baik barang yang diperjual-belikan itu berjenis dan berat sama ataupun berlainan.

c. Riba al-Yad ialah melaksanakan jual beli barang-barang ribawi yang sejenis tanpa ada persyaratan penangguhan pada masa akad. Namun, dalam kenyataannya penyerahan barang tersebut dilaksanakan dalam keadaan tertangguh.

d. Riba Qardh, ialah mengambil suatu manfaat atau tingkat kelebihan tertentu yang disyaratkan terhadap yang berutang (muqtaridh).

\section{Dual Banking System Dalam Perbankan Indonesia}

\section{Struktur Perbankan Indonesia}

a. Sistem Bank Tunggal (Unit Banking System),

adalah sejumlah bank yang berdiri sendiri dan tidak memiliki cabang atau perwakilan. Pengertian tidak memiliki cabang adalah dalam arti dapat mendirikan cabang-cabang tetapi hanya dapat beroperasi di suatu daerah. (Sunggono, 1995) 
b. Multiple Office banking System

Adalah beberapa kantor bank yang beroperasi dalam satu kesatuan hukum. Ada 3 (tiga) jenis:
1). Branch Banking System
2). Chain Banking System
3). Group Banking System

\section{c. Dual banking System}

Istilah Dual banking System ini digunakan untuk bank konvensional yang membuka kantor cabang pembantu syariah, atau bank yang berdasarkan prinsip bunga yang membuka kantor cabang pembantu yang menggunakan Prinsip Syariah Islam. (Hilman, 2003) Dengan diberlakukannya Undang-undang Nomor 21 Tahun 2008 Tentang Perbankan Syariah (UUPS) Jo. Undang-undang Nomor 10 Tahun 1998 perubahan atas Undang-undang Nomor 7 Tahun 1992 Tentang Perbankan (UUP), maka secara implisit dan eksplisit dalam Pasal 1 angka 3 telah menetapkan boleh beroperasinya "perbankan dengan sistem ganda" (Dual Banking System), yakni perbankan konvensional dan perbankan syariah. Operasionalisasi Dual Banking System, yaitu melaksanakan bank konvensional dan bank syariah secara berdampingan dalam satu business entity dengan cara memberikan pelayanan jasa perbankan bagi masyarakat. Pelaksanaannya diatur dalam berbagai peraturan perundang-undangan, yaitu Peraturan Bank Indonesia (PBI) dan Surat Edaran Bank Indonesia (SEBI).

\section{Syarat Dan Prosedur Dual Banking System}

Syarat dan prosedur Dual Banking System terdiri atas:

a. Pendirian kantor cabang atau kantor dibawah kantor cabang baru yang khusus hanya menjalankan kegiatan usahanya berdasarkan prinsip syariah;

b. Pengubahan kantor cabang atau kantor dibawah kantor cabang yang semula melakukan kegiatan usaha secara konvensional untuk selanjutnya hanya melakukan kegiatan usaha berdasarkan prinsip syariah. (Dewi, 2005)

\section{Karakteristik Dual Banking System}

Bank dengan Dual Banking System mempunyai karakteristik sebagai berikut:

a. Kantor Cabang Syariah.

Kantor Cabang bank umum konvensional yang telah diberi ijin usaha melakukan kegiatan usaha berdasarkan prinsip syariah harus mencantumkan kata "Kantor Cabang Syariah".

b. Unit Usaha Syariah.

Kantor-kantor cabang dari bank umum konvensional pada dasarnya merupakan unit yang mempunyai karakterisik kegiatan usaha yang berbeda, serta mempunyai pencatatan pembukuan yang terpisah dari kantor-kantor operasionalnya. Oleh karena itu bank umum dengan dual banking system juga 
diwajibkan membentuk Unit Usaha Syariah (UUS) yang berfungsi sebagai kantor induk bagi seluruh kantor cabang syariah. (Arifin, 2006)

c. Modal Kantor Cabang Syariah

Bagi bank umum konvensional yang membuka cabang syariah wajib menyediakan modal kerja untuk seriap kantor. Modal kerja tersenut harus disisihkan oleh bank dalam suatu rekening tersendiri atas nama pimpinan unit usaha syariah yang dapat digunakan untuk membayar operasional maupun non operasional kantor cabang syariah. Penyisihan modal tersebut dimaksudkan agar dana yang dikelola oleh kantor cabang syariah tidak tercampur dengan dana kantor induk yang beroperasi secara konvensional.

\section{Mekanisme Perbankan Pada Sistem Bank Konvensional Dan Pada Sistem Bank Syariah}

Kecenderungan masyarakat menggunakan sistem bunga (interest atau usury) lebih bertujuan untuk mengoptimalkan pemenuhan kepentingan pribadi, sehingga kurang memperhatikan dampak sosial yang ditimbulkannya. Berbeda dengan sistem bagi hasil (proft sharing), sistem ini berorientasi pemenuhan kemaslahatan hidup umat manusia. Hal mendasar yang membedakan antara Bank Syariah dan Bank Konvensional adalah terletak pada pengembalian dan pembagian keuntungan yang diberikan oleh nasabah kepada bank dan/atau yang diberikan oleh bank kepada nasabah. Sehingga terdapat istilah bunga dan bagi hasil. Perbedaan bunga dan bagi hasil, diantara keduanya dapat dijelaskan dalam tabel, sebagai berikut: (Muhamad, 2006)

Tabel 2. Perbedaan Sistem Bunga dengan Sistem Bagi Hasil

$$
\text { Hal Sistem Bunga Sistem Bagi Hasil }
$$

\begin{tabular}{|c|c|c|}
\hline $\begin{array}{l}\text { Penentuan } \\
\text { besarnya hasil }\end{array}$ & Sebelumnya & $\begin{array}{l}\text { Sesudah berusaha, sesudah ada } \\
\text { untungnya }\end{array}$ \\
\hline $\begin{array}{l}\text { Yang ditentukan } \\
\text { sebelumnya }\end{array}$ & $\begin{array}{l}\text { Bunga, besarnya nilai } \\
\text { rupiah }\end{array}$ & $\begin{array}{l}\text { Menyepakati proporsi pembagian untung } \\
\text { untuk masing-masing pihak misalnya } 50 \text { : } \\
50,40: 60,35: 65 \text {, dst. }\end{array}$ \\
\hline $\begin{array}{l}\text { Jika terjadi } \\
\text { Kerugian }\end{array}$ & Ditanggung nasabah saja & $\begin{array}{l}\text { Ditanggung kedua belah pihak, nasabah } \\
\text { dan bank }\end{array}$ \\
\hline $\begin{array}{l}\text { Dihitung dari } \\
\text { mana? }\end{array}$ & $\begin{array}{l}\text { Dari dana yang } \\
\text { dipinjamkan, fixed/ tetap. }\end{array}$ & $\begin{array}{l}\text { Dari untung yang bakal diperoleh, belum } \\
\text { tentu besarnya }\end{array}$ \\
\hline $\begin{array}{l}\text { Titik perhatian } \\
\text { proyek/Usaha }\end{array}$ & $\begin{array}{l}\text { Besarnya bunga yang } \\
\text { harus dibayar } \\
\text { nasabah/pasti diterima } \\
\text { bank }\end{array}$ & $\begin{array}{l}\text { Keberhasilan proyek/usaha jadi perhatian } \\
\text { bersama: nasabah dan bank }\end{array}$ \\
\hline Berapa besarnya? & $\begin{array}{l}\text { Pasti: (\%) kali jumlah } \\
\text { pinjaman yang telah pasti } \\
\text { diketahui }\end{array}$ & $\begin{array}{l}\text { Proporsi (\%) kali jumlah untung yang } \\
\text { belum diketahui = belum diketahui }\end{array}$ \\
\hline Status hukum & $\begin{array}{l}\text { Berlawanan dengan QS. } \\
\text { Luqman : } 34\end{array}$ & Melaksanakan QS Luqman : 34 \\
\hline
\end{tabular}




\begin{tabular}{lll}
\hline \multicolumn{1}{c}{ Keterangan } & Bank Konvensional & \multicolumn{1}{c}{ Bank Syariah } \\
\hline Akad dan Aspek legalitas & Hukum Positif & $\begin{array}{l}\text { Hukum Islam \& Hukum } \\
\text { Positif }\end{array}$ \\
\hline Struktur Organisasi & Tidak ada DSN dan DPS & $\begin{array}{l}\text { Ada Dewan Syariah } \\
\text { Nasional (DSN) dan } \\
\text { Dewan Pengawas Syariah } \\
\text { (DPS) }\end{array}$ \\
\hline Investasi & Halal dan Haram & Halal \\
\hline Prinsip Operasional & Perangkat Bunga & $\begin{array}{l}\text { Perangkat Bagi hasil, jual } \\
\text { beli, sewa (ijarah) }\end{array}$ \\
\hline Tujuan & Profit Oriented & Profit dan falah oriented \\
\hline Hubungan Nasabah & Debitur dan Kreditur & Kemitraan \\
\hline Lembaga Penyelesaian & BANI \& Pengadilan Niaga & Debitur dan Kreditur \\
Sengketa & & \\
\hline
\end{tabular}

Sementara itu, untuk memberikan keyakinan pada masyarakat yang masih meragukan kesyariahan operasional Perbankan Syariah selama ini, diatur pula kegiatan usaha yang tidak bertentangan dengan Prinsip Syariah meliputi kegiatan usaha yang tidak mengandung unsur-unsur riba, maisir, gharar, haram, dan zalim. Pasal 18 Undang-undang Perbankan Syariah (UUPS) menentukan jenis-jenis produk Bank Syariah, yaitu: (Antonio, 1999)

a. Prinsip titipan atau simpanan (Al-Wadi'ah)

b. Bagi hasil (profit sharing);

1) Al-Musyarakah (partnership, Project Financing Participation),

2) Al-Mudharabah (trust financing, trust investment),

3) Al-Muzara'ah (Harvest-Yield profit sharing),

4) Al-Musaqah (plantation management fee based on certain portion of yield)

c. Jual beli (sale and purchase);

5) Bai' Al-Murabahah (deferred payment sale),

6) Bai' As-Salam (in-front payment sale),

7) Bai' Al-Istishna' (purchase by order or manufacture),

d. Sewa (operational lease and financial lease);

8) Al-ijarah (operational lease),

9) Al-ijarah al-Muntahia bit-tamlik (Financial Lease with purchase option),

e. Jasa (fee-based services);

10) Al-wakalah (deputyship)

11) Al-Kafalah (guaranty),

12) Al-Hawalah (transfer service),

13) Al-Rahn (mortgage),

14) Al-Qardh (soft and benevolent loan). 


\section{Fungsi Bank Syariah Dalam Pengembangan Perbankan Indonesia}

Didalam pelaksanaannya, menurut Pasal 4 ayat (1), (2), (3), dan (4) Undang-undang Perbankan Syariah (UUPS) menyatakan bahwa Bank Syariah dan Unit Usaha Syariah (UUS) wajib menjalankan fungsi menghimpun dan menyalurkan dana masyarakat. Hal tersebut mengartikan bahwa Bank Syariah mempunyai dua peran utama, yaitu: (Muhamad, 2007

1. Sebagai Badan Usaha (Tanwi), bank syariah mempunyai beberapa fungsi, yakni sebagai;

a. manajer investasi, bank syariah melakukan penghimpunan dana dari para investor/nasabahnya dengan prinsip titipan (wadi'ah yad dhamanah), bagi hasil (mudharabah) atau sewa (ijarah).

b. investor, bank syariah melakukan penyaluran dana melalui kegiatan investasi dengan prinsip bagi hasil, jual beli atau sewa; dan

c. Penyedia jasa pelayanan, bank syariah menyediakan jasa keuangan, jasa non keuangan dan jasa keagenan. Pelayanan jasa keuangan antara lain dilakukan dengan prinsip pemberian mandat (wakalah), bank garansi (kafalah), pengalihan utang (hiwalah), jaminan utang atau gadai (rahn), pinjaman dana kebajukan untuk dana talangan (qardh), jual beli valuta asing (sharf), dan lain-lain. Pelayanan jasa nonkeuangan dalam bentuk wadi'ah yad amanah (safe deposit box) dan pelayanan jasa keagenan dengan prinsip mudharabah muqayyadah.

2. Badan sosial (Maal), bank syariah mempunyai fungsi sebagai pengelola dana sosial, untuk penghimpunan dan penyaluran zakat, infaq, dan shadaqah serta wakaf (ZISW) serta penyaluran pinjaman kebajikan ( qhardhul hasan).

Penjelasan Pasal 4 ayat (2) Undang-undang Perbankan Syariah (UUPS), yang dimaksud dengan "dana sosial lainnya", antara lain adalah penerimaan Bank yang berasal dari pengenaan sanksi terhadap Nasabah (ta'zir).

\section{TUJUAN DAN MANFAAT PENELITIAN}

\section{Tujuan Penelitian}

1. Memperoleh kepastian penerapan sistem bagi hasil dalam perjanjian pembiayaan Syariah yang tidak menggunakan mekanisme pembagian untung dan rugi (profit and loss sharing) terhadap pengembangan Bank Syariah;

2. Mendapatkan gambaran akibat hukum kebijakan Peraturan Bank Indonesia (PBI) dikaitkan dengan Undang-undang Perbankan Syariah terhadap pengembangan Bank Syariah ;

3. Mencari dan menentukan konsep pembiayaan syariah yang dapat memberi rasa keadilan bagi bank dan nasabah dalam pengembangan sistem perbankan Indonesia. 


\section{Manfaat Penelitian}

Hasil penelitian ini diharapkan dapat memberikan manfaat, baik yang bersifat teoritis, maupun yang bersifat praktis, memberikan kontribusi bagi pengembangan ilmu hukum dan menambah kepustakaan mengenai hukum perbankan syariah, khususnya yang berkaitan dengan perjanjian pembiayaan syariah dan Bagi Hasil. Menjadi bahan masukan dan sumber informasi bagi pihak-pihak yang berkepentingan terutama masyarakat pengguna bank, ulama, yang diwadahi Majelis Ulama Indonesia (MUI) dan kalangan usaha perbankan (konvensional dan syariah), baik bank pemerintah maupun bank swasta, khususnya institusi perbankan di Indonesia (BI). Menjadi suatu sumbangan pikiran bagi pemerintah, kepada Badan Pembinaan Hukum Nasional (BPHN) dan lembaga legislatif, kepada Dewan Perwakilan Rakyat (DPR) dalam pembentukan hukum perbankan nasional (Konvensional dan Syariah), khususnya peraturan pemerintah sebagai peraturan pelaksanaan dari Undang-undang Perbankan Syariah dan menjadi bahan penelitian lebih lanjut.

\section{METODE PENELITIAN}

Penelitian ini bersifat deskriptif analisis dengan metode pendekatan yang dilakukan adalah yuridis normatif, dalam arti meneliti, dan mengkaji bahan pustaka (obyek) tersebut melalui sumber hukumnya yang menyangkut perundangundangan mengenai sistem Bagi Hasil. Untuk mempertajam analisis maka diperlukan studi perbandingan hukum (comparative study). Selanjutnya data yang diperoleh dari hasil penelitian, akan dianalisis secara yuridis kualitatif.

\section{HASIL DAN PEMBAHASAN}

\section{Implementasi Bagi Hasil Dalam Pengembangan Bank Syariah}

Dominasi pembiayaan nonbagi hasil, telah terjadi sejak lama dan tidak ada kecenderungan untuk berubah. Bahkan secara perlahan pembiayaan bagi hasil menurun sehingga terlihat pembiayaan bagi hasil menjadi pembiayaan sekunder. Skim bagi hasil pada dasarnya merupakan model pembiayaan primer bank syariah, sebagaimana tercantum dalam Penjelasan Atas Undang-undang Perbankan Syariah sebagai berikut:

"....Salah satu prinsip dalam ekonomi Islam adalah larangan riba dalam berbagai bentuknya, dan menggunakan sistem antara lain prinsip bagi hasil. Dengan prinsip bagi hasil, Bank Syariah dapat menciptakan iklim investasi yang sehat dan adil karena semua pihak dapat saling berbagi baik keuntungan maupun potensi risiko yang timbul sehingga akan menciptakan posisi yang berimbang antara bank dan nasabahnya. oleh pemilik modal saja, tetapi juga oleh pengelola modal. ...".

Pada praktiknya, penerapan skim bagi hasil oleh bank syariah dapat bervariasi. Variasi dari skim bagi hasil tergantung dari beberapa faktor, antara lain; level transparansi sistem, adanya benchmark dalam sistem, preferensi investor, rasio kekayaan dan kebutuhan dasar. Implikasi dari tingginya minat nasabah 
terhadap pembiayaan nonbagi hasil, diakibatkan munculnya persepsi sebagian besar di kalangan masyarakat bahwa perbankan syariah hampir tidak ada bedanya dengan perbankan konvensional. Perbankan syariah hanya merupakan pergantian nama saja, sedangkan mind-set pelakunya tetaplah konvensional. Hal demikian terjadi juga di negara-negara yang menerapkan perbankan syariah, terutama di negara-negara yang menerapkan sistem perbankan ganda (dual banking system), seperti di Mesir, dan Malaysia.

Landasan utama pembiayaan bagi hasil adalah tingkat kepercayaan yang tinggi dari bank kepada nasabah. Kepercayaannya itu pihak bank (bank syariah) harus siap untuk menanggung risiko tidak memperoleh pendapatan dan bahkan risiko kehilangan modal, sebagaimana diuraikan terdahulu. Pada kenyataannya banyak pengalaman pada bank-bank syariah di dunia yang diperdaya oleh nasabahnya, misalnya tidak melaporkan hasil usaha dengan jujur atau penggunaan dana tidak sesuai dengan tujuan. Di samping itu, fakta standar moral masyarakat terkait i'tikad untuk membayar utang (niat bayar) yang masih rendah membuat bank sulit percaya begitu saja kepada nasabahnya (Ascarya, 2007). Faktor rendahnya kepercayaan kepada nasabah dan tingginya risiko penyalahgunaan pembiayaan mudharabah, membuat pembiayaan tersebut diplesetkan menjadi "Mudah Rebah".

\section{Manfaat Perjanjian Pembiayaan Syariah Dalam Kerjasama kemitraan Usaha Kecil dan Menengah (UKM)}

Ketentuan tersebut, sejalan dengan Pasal 35 ayat (1) Undang-undang Perbankan Syariah (UUPS) dan Penjelasannya menyatakan, Bank Syariah dan Unit Usaha Syariah (UUS) dalam melakukan kegiatan usahanya wajib menerapkan prinsip kehati-hatian". Penjelasan Pasal 35 Ayat (1), menyatakan dalam rangka menjamin terlaksananya pengambilan keputusan dalam pengelolaan bank yang sesuai dengan prinsip kehati-hatian, Bank memiliki dan menerapkan, antara lain, sistem pengawasan intern". Selain itu, Pasal 36 mengatur mengenai penyaluran Pembiayaan dan melakukan kegiatan usaha lainnya, Bank Syariah dan Unit Usaha Syariah (UUS) wajib menempuh cara-cara yang tidak merugikan Bank Syariah. Bahkan Pasal 37 Undang-undang Perbankan Syariah (UUPS) serta Penjelasannya sebagai berikut, Ayat (1): "Dalam menyalurkan Pembiayaan dan melakukan kegiatan usaha lainnya, Bank Syariah dan Unit Usaha Syariah (UUS) wajib menempuh cara-cara yang tidak merugikan Bank Syariah dan/atau Unit Usaha Syariah (UUS) dan kepentingan Nasabah yang mempercayakan dananya". Pasal 37 Ayat (1) Undang-undang Perbankan Syariah (UUPS) menyebutkan: "Bank Indonesia menetapkan ketentuan mengenai batas maksimum penyaluran dana berdasarkan Prinsip Syariah, pemberian jaminan, penempatan investasi surat berharga yang berbasis syariah, atau hal lain yang serupa, yang dapat dilakukan oleh Bank Syariah dan Unit Usaha Syariah (UUS) kepada Nasabah Penerima Fasilitas atau sekelompok Nasabah Penerima Fasilitas yang terkait, termasuk 
kepada perusahaan dalam kelompok yang sama dengan Bank Syariah dan Unit Usaha Syariah (UUS) yang bersangkutan".

Penjelasan Pasal 37 Ayat (1) Undang-undang Perbankan Syariah (UUPS), menyatakan: "Penyaluran dana berdasarkan Prinsip Syariah oleh Bank Syariah dan Unit Usaha Syariah (UUS) mengandung risiko kegagalan atau kemacetan dalam pelunasannya sehingga dapat berpengaruh terhadap kesehatan Bank Syariah dan Unit Usaha Syariah (UUS). Mengingat bahwa penyaluran dana dimaksud bersumber dari dana masyarakat yang disimpan pada Bank Syariah dan Unit Usaha Syariah (UUS), risiko yang dihadapi Bank Syariah dan Unit Usaha Syariah (UUS) dapat berpengaruh pula kepada keamanan dana masyarakat tersebut. Oleh karena itu, untuk memelihara kesehatan dan meningkatkan daya tahannya, bank diwajibkan menyebar risiko dengan mengatur penyaluran kredit atau pemberian pembiayaan berdasarkan Prinsip Syariah, pemberian jaminan ataupun fasilitas lain sedemikian rupa sehingga tidak terpusat pada Nasabah debitur atau kelompok Nasabah debitur tertentu".

Usaha Kecil Menengah (UKM) sebagai salah satu sasaran perbankan syariah sekaligus pelaku usaha, bersama-sama pemerintah dan lembaga-lembaga di sektor keuangan memiliki peranan dalam membangun ekonomi Indonesia. Usaha Kecil Menengah (UKM) sebagai pelaku usaha memiliki eksistensi penting namun dianggap "terlupakan" dalam percaturan kebijakan. Pemerintah sebagai pembuat dan pengatur kebijakan diharapkan dapat memberikan iklim yang kondusif bagi dunia usaha, sehingga lembaga keuangan baik perbankan (khususnya perbankan syariah) maupun bukan perbankan serta pelaku usaha (dalam hal ini UKM) dapat memanfaatkan kebijakan dan melaksanakan kegiatan usaha dengan lancar yang pada akhirnya dapat mendorong percepatan pembangunan ekonomi. (Setyobudi, 2005)

Selanjutnya, pembiayaan syariah bagi UKM melalui jasa perbankan didasarkan pada keunggulan-keunggulan yang dimilikinya akan memberikan manfaat. Maka tidak ada alasan bagi bank syariah untuk tidak melakukan suatu kemitraan usaha dengan UKM dan meminjamkan dana tanpa memungut bunga, tetapi berbagi untung dan risiko. Sebagaimana Pasal 25 ayat (1) dan Pasal 26 huruf (f) Undangundang Nomor 20 Tahun 2008 Tentang Usaha Mikro Kecil dan Menengah (selanjutnya ditulis Undang-undang Tentang UMKM) yang menyatakan bahwa: "Pemerintah, Pemerintah Daerah, Dunia Usaha, dan masyarakat memfasilitasi, mendukung, dan menstimulasi kegiatan kemitraan, yang saling membutuhkan, mempercayai, memperkuat, dan menguntungkan". "...... Salah satu bentuk kemitraan yang digunakan yaitu bagi hasil dan kerjasama operasional".

Berdasarkan uraian tersebut di atas, menunjukkan bahwa sistem bagi hasil dalam perjanjian pembiayaan syariah bagi UKM, merupakan nasabah perbankan syariah paling besar dan memberikan manfaat, pertama; Perjanjian pembiayaan bagi hasil dengan sistem bagi hasil (profit-loss sharing) oleh perbankan syariah memungkinkan kemitraan yang saling mendukung antara pengusaha dan pemilik 
dana, sehingga mengatasi masalah asymmetric information dan credit rationing sebagaimana diungkapkan oleh Dhumale dan Sapcanin:

"Again, the profit and loss sharing schemes advocated under Islamic principle of cooperation (shirakat/syirkah) allow all parties-induding investors, savers, and financial institution-to play an active role in the economic process and avoid credit rationing problem"

\section{Konsep Pembiayaan Syariah Dengan Sistem Bagi Hasil Dalam Perkembangan Bank Syariah Di Indonesia}

Pembiayaan Syariah berbasis bagi hasil merupakan sistem, bila dijelaskan lebih lanjut merupakan frase yang mewakili berbagai bentuk manfaat, dan jenisjenis perjanjian yang dibolehkan secara Muamalat. Secara umum transaksi dalam bank syariah haruslah mengacu kepada prinsip-prinsip syariah yang diatur dalam Undang-undang Perbankan Syariah berdasarkan Fatwa Dewan Syariah Nasional (DSN). Hal itupun dipertegas di dalam Pasal 1 butir 13 Undang-undang Perbankan (UUP) Jo. Pasal 1 angka (12) Undang-undang Perbankan Syariah (UUPS), sebagai berikut: "Prinsip Syariah adalah aturan perjanjian berdasarkan hukum Islam antara bank dan pihak lain untuk penyimpanan dana dan atau pembiayaan kegiatan usaha, atau kegiatan lainnya yang dinyatakan sesuai dengan syariah, antara lain pembiayaan berdasarkan prinsip bagi hasil (mudharabah), pembiayaan berdasarkan prinsip penyertaan modal (musharakah, prinsip jual beli barang dengan memperoleh keuntungan (murabahah), atau pembiayaan barang modal berdasarkan prinsip sewa murni tanpa pilihan (ijarah), atau dengan adanya pilihan pemindahan kepemilikan atas barang yang disewa dari pihak bank oleh pihak lain (ijarah wa iqtina)" Pasal 1 angka (12) UUPS yang berbunyi sebagai berikut: "Prinsip Syariah adalah prinsip hukum Islam dalam kegiatan perbankan berdasarkan fatwa yang dikeluarkan oleh lembaga yang memiliki kewenangan dalam penetapan fatwa di bidang syariah"

Selanjutnya, di dalam pembiayaan syariah dengan sistem bagi hasil ada kesetaraan antara pemilik modal (shahibul maal) dan pengusaha (mudharib) sebagai pengelola modal. Pemilik modal (shahibul maal) akan untung bila pengusaha (mudharib) juga mendapat keuntungan, dengan porsi (nisbah) bagi hasil yang disepakati di awal dalam bentuk aqad. Sehingga bagi hasil itu di dalamnya ada kemakmuran, ada keadilan di samping kesetaraan. Kemakmuran terjadi karena ekonomi tumbuh, bukan hanya pada pengusaha besar yang kuat secara modal, tetapi juga pengusaha menengah dan kecil yang mendapat kucuran modal tanpa dibebani oleh bunga yang tinggi. Keadilan terjadi karena tidak ada yang dirugikan sepihak, kalau untung, untung bersama, kalau rugi ditanggung sama-sama.

Pembiayaan syariah mengandung arti bahwa pihak-pihak yang terlibat dalam kerjasama usaha tersebut, ikut serta berbagi hasil (untung maupun rugi) dengan bank syariah dalam menjalankan usahanya. Pada konsep idealnya, jika bank syariah rugi, kerugian ditanggung bersama nasabah yang berinvestasi (profit and 
loss sharing). Dalam praktiknya, masyarakat tidak siap menanggung rugi dan tidak siap pokok dananya berkurang. Hal ini pula yang mendasari bank syariah akhirnya menerapkan mekanisme berbagi pendapatan (revenue sharing) bukannya mekanisme berbagi keuntungan (profit sharing). Dengan kata lain bank syariah juga enggan berbagi kerugian dalam pembiayaan. Oleh karena, bank syariah harus mampu menjaga dana nasabah tidak berkurang nilainya, meskipun pembiayaannya merugi.

Kegiatan bisnis perbankan syariah di luar aspek syariah mencakup berbagai aspek hukum termasuk hukum perbankan, hukum perusahaan dan hukum dagang. Karena hukum yang diberlakukan tersebut bersifat umum, maka pada bagianbagian tertentu akan terdapat permasalahan yang tidak terhindarkan lantaran adanya kontradiksi antara hukum positif yang berlaku dengan prinsip-prinsip syariah dalam operasional bank syariah, dan dengan demikian akan juga mempengaruhi hubungan antara bank syariah dengan nasabahnya. Seperti diketahui dalam usaha perbankan telah terjadi perubahan dan pembaharuan hukum di bidang perbankan syariah (Hasan,...). Pembaharuan tersebut perlu dilakukan dan harus tetap diperhatikan bidang-bidang tertentu yang sifatnya tidak netral (misalnya dalam bidang hukum agama, keluarga dan waris), dalam bidang ini pencerminan kepribadian masyarakat akan menjiwai bidang tersebut. Sedangkan dalam bidang hukum yang sifatnya netral karena sifat interaksi modern dengan memperhatikan perkembangan yang terjadi di negara lain.

Perbankan syariah saat ini menurut hemat penulis, perlu lebih kreatif untuk mencoba gagasan Muhammad Yunus dalam program Grameen Bank di Bangladesh, mencari orang-orang miskin, kemudian dilatih berwirausaha dan diberikan pembiayaan tanpa bunga dan bagi hasil, artinya Muhammad Yunus mengalokasikan sumber daya keuangannya dalam jumlah besar untuk orangorang miskin. Pemikiran tersebut jelas tidak menguntungkan bagi bank. Bahkan dalam jangka panjang sekalipun tak ada untungnya. Tapi seandainya orang miskin yang diberikan pinjaman qardhul hasan itu berhasil dan akan meminjam dalam jumlah besar, bisa menjadi pasar perbankan tersebut. Bank syariah sudah melakukan hal tersebut dengan menyalurkan 2,5 persen labanya pada lembaga zakat, infaq, shadaqah, dan wakaf (zisw). Jika dianalogikan, di Bangladesh Grameen Bank dan di Indonesia banyak bank syariah. Namun kenyataannya orang miskin di Indonesia masih belum terangkat, karena bank syariah belum banyak mengembangkan akad-akad syariah, sehingga yang terkesan adalah akad Murabahah (jual beli) saja. akad-akad Murabahah itu pun lebih diperuntukan orang kaya. Di Indonesia orang miskin pekerjaannya meminta-minta, kalau di Bangladesh Muhammad Yunus mampu berhasil mengubah orang miskin menjadi pengusaha dikarenakan program permodalan yang dibentuk berhasil dan dunia mengakuinya. Sementara keberadaan bank syariah di Indonesia belum mengangkat orang miskin yang jumlahnya lebih banyak dari pada di Bangladesh.

Penulis cermati dari sistem perkreditan Grameen Bank, meninggalkan semua prinsip-prinsip Bank komersial, tidak mengenal keuntungan dan transaksi dibuat 
sesederhana mungkin. Bahkan, Grameen Bank yang dikelola pemenang Nobel Muhammad Yunus di Bangladesh bukan Bank Syari'ah. Namun beberapa sisi justru lebih Islami daripada sebagian Bank Syariah yang ada di Indonesia. Grameen Bank tidak membutuhkan jaminan. Jadi orang miskin, khususnya wanita, bisa meminjam tanpa perlu memberi jaminan. Meski tanpa jaminan, tingkat pengembalian nasabah Grameen Bank tetap tinggi.Di Indonesia, kenyataannya justru Bank Syariah seringkali lebih mahal pengembaliannya daripada Bank Konvensional. Sebagai contoh untuk pinjaman Rp 50 juta dalam tempo 10 tahun, total pinjaman yang harus dikembalikan di Bank Konvensional hanya Rp 98 juta. Sementara di Bank Syariah ternyata Rp 146 juta. Meski menurut staf Bank Syariah nilai tersebut tidak akan naik, tapi justru bisa kurang. Pinjaman di Grameen Bank dapat dirasakan manfaatnya bagi rakyat banyak. Sekitar 50 juta orang merasakannya dan terlepas dari kemiskinan yang menahun. Pinjaman yang diberikan tidak banyak. Pertama pada tahun 1974 hanya US $\$ 27$ ke 42 keluarga dan satu orang dipinjami kurang dari 1 dollar.

Menyitir ayat suci Al Qur'an, yang artinya: "Dan jika (orang yang berhutang itu) dalam kesukaran, maka berilah tangguh sampai dia berkelapangan. Dan menyedekahkan (sebagian atau semua utang) itu, lebih baik bagimu, jika kamu mengetahui." [Al Baqarah:280]. "Allah memusnahkan riba dan menyuburkan sedekah..." [Al Baqarah:276]. Ayat di atas jelas Allah Swt. memerintahkan untuk mempermudah. Bahkan sampai ke tingkat sedekah. Jadi meski tidak mampu memberi sedekah, harusnya Bank Syariah bisa lebih ringan pembayarannya ketimbang Bank Konvensional. Dalam praktiknya Bank Syariah justru lebih besar pengembaliannya hingga lebih memberatkan nasabahnya dibanding Bank Konvensional, tentunya akan menimbulkan anggapan Bank Syariah 'lebih riba' daripada Bank Konvensional. Untuk itu Bank Syariah harus memakai strategi, yaitu sistem bagi hasil mendasarkan bagi untung dan rugi (profit and Loss Sharing) bukan mendasarkan bagi pendapatan (revenue sharing) (Media Islam).

Undang-undang Nomor 21 Tahun 2008 Tentang Perbankan Syariah (UUPS) menyatakan dalam konsiderannya, sebagai berikut: " ...........sejalan dengan tujuan pembangunan nasional Indonesia untuk mencapai terciptanya masyarakat adil dan makmur berdasarkan demokrasi ekonomi, dikembangkan sistem ekonomi yang berlandaskan pada nilai keadilan, kebersamaan, pemerataan, dan kemanfaatan yang sesuai dengan prinsip syariah;........kebutuhan masyarakat Indonesia akan jasa-jasa perbankan syariah semakin meningkat; dan perbankan syariah memiliki kekhususan dibandingkan dengan perbankan konvensional". Dikatakan Mochtar Kusumaatmadja bahwa hukum sebagai sarana ketertiban dalam pelaksanaan pembangunan. Dalam hal ini, pembangunan hukum melalui peraturan perundangan dalam rangka memperbaharui peraturan perundangan yang sebelumnya belum ada. Berlakunya Undang-undang Perbankan Syariah, maka diharapkan hukum sebagai acuan dalam melakukan kegiatan ekonomi secara teratur atau tertib untuk mencapai tujuan yang diinginkan (Kusumaatmadja). 
Selanjutnya, menurut Mochtar Kusumaatmadjadikatakan bahwa sistem bagi hasil yang sebelumnya dikenal dalam hukum adat ini, kemudian berkembang ke permukaan antara lain dalam kontrak bagi hasil. Kontrak bagi hasil tersebut ternyata memadai untuk menampung kebutuhan yang diterapkan perusahaan tambang dan migas asing dalam pengeboran minyak yaitu Production Sharing. Konsep baru yang didasarkan atas hukum adat ini ternyata selain melindungi kepentingan nasional seperti Indonesiasi dan alih teknologi, juga bermanfaat dalam konservasi kekayaan tambang dan migas. Selanjutnya, penerapan konsep Pembiayaan Syariah dengan sistem bagi hasil mendasarkan kepada bagi untung dan rugi (profit \& loss sharing) dapat memberikan kontribusi dalam pengembangan Bank Syariah di Indonesia. Selain itu konsep pembiayaan syariah dengan sistem bagi hasil tersebut, diharapkan dapat memberi keuntungan dan rasa keadilan bagi bank dan nasabah dalam pengembangan sistem perbankan Indonesia (Kusumaatmadja, 1995).

\section{KESIMPULAN DAN SARAN \\ Kesimpulan}

1. Penerapan sistem bagi hasil dalam pembiayaan syariah yang tidak menggunakan mekanisme pembagian untung dan rugi (profit and loss sharing mechanism) terhadap pengembangan bank syariah adalah suatu sistem usaha yang didasarkan pada mekanisme perhitungan bagi hasil didasarkan kepada total seluruh pendapatan yang diterima sebelum dikurangi dengan biaya-biaya yang telah dikeluarkan untuk memperoleh pendapatan tersebut.

2. Akibat hukum kebijakan Peraturan Bank Indonesia (PBI) dikaitkan dengan Undang-undang Perbankan Syariah (UUPS) terhadap pengembangan Bank Syariah adalah tidak cukup untuk mempercepat perkembangan bank syariah di Indonesia, saat ini yang terpenting diselesaikan berbagai persoalan yang masih berpotensi dapat menghambat laju pertumbuhan perbankan syariah.

3. Konsep pembiayaan syariah yang dapat memberi rasa keadilan bagi bank dan nasabah dalam pengembangan sistem perbankan Indonesia adalah dalam setiap transaksi atau akad/perjanjian pembiayaan di bank syariah menggunakan sistem bagi hasil dengan mekanisme bagi untung dan bagi rugi (profit and Loss sharing mechanism) yang mengandung dimensi keadilan distributif dan kesetaraan, yaitu hubungan kemitraan usaha yang bersifat participatory-emancipatory, bukan hubungan subordinasi yang discriminatory.

\section{Saran}

1. Peningkatan kualitas dan kuantitas Sumber Daya Insani/Islami dapat dilakukan secara berjenjang, dimulai dengan jenjang jabatan yang paling atas, khususnya terkait dengan fit and proper test direktur utama perbankan syariah yang berkesinambungan secara berkala dan harus dibedakan dengan fit and proper test bagi pimpinan bank konvensional. Strategi peningkatan kualitas dan kuantitas SDI, yaitu jangka pendek dan jangka panjang. 
2. Pemberlakuan Undang-undang Nomor 21 Tahun 2008 Tentang Perbankan Syariah dapat disikapi dengan diimplementasikan, dikaji dan dievaluasi. Apabila terdapat hal-hal yang memberatkan, menghambat, atau memerlukan penyempurnaan, maka diupayakan inventarisasi sebagai bahan revisi dan penyempurnaan (melalui seminar dan diskusi).

3. Masalah pemurnian terhadap pelaksanaan praktik perbankan syariah merupakan agenda utama harus terus mendapat perhatian. Proses pemurnian, diarahkan untuk terus-menerus memperbaiki praktik-praktiknya, yaitu meningkatkan kemurniannya terhadap prinsip-prinsip syariah yang harus dipegang teguh (syariah compliance).

\section{DAFTAR PUSTAKA}

\section{Buku}

Ahmed, S. (2006). Islamic Banking Finance And Insurance, A Global Overview, Zafar Sdn Bhd., Kualalumpur, Malaysia.

Amalia, E. (2009). Keadilan Distributif Dalam Ekonomi Islam Penguatan Peran LKM Dan UKM di Indonesia, PT. RajaGrafindo Persada, Jakarta, 2009.

Anshori, A. G. (2007) Perbankan Syariah Indonesia, Gajah Mada University Press, Yogyakarta.

Antonio, S. M. (1999). Bank Syariah : Wacana Ulama \& Cendekiawan. Tazkia Institute, Jakarta. hal 83-134

Ascarya, (2007). Akad \& Produk Bank Syariah, PT. Raja Grafindo Persada, Jakarta.

Ashshofa, B. (2004). Metode Penelitian Hukum, Rineka Cipta, Jakarta.

Cambell, B. H. (1991). Blak's Law Dictionary, Abridged, Sixth Edition, West Published.

Dewi, G. (2006). Aspek-aspek Hukum Perbankan dan Pengasuransian Syariah di Indonesia, Prenada Media Group. Hal. 65

Departemen Pendidikan dan Kebudayaan, (1997). Kamus Besar Bahasa Indonesia. (Ed.) Balai Pustaka, Jakarta

Direktorat Perbankan Syariah, (2006). Laporan Perkembangan Syariah Tahun 2006, Direktorat Perbankan Syariah, Bank Indonesia, hal. 19

Echols, J.M dan Shadily, H. (1981). Kamus Inggris Indonesia. (Eds.). PT Gramedia, Jakarta, hal. 575 
Esposito, J. L. (2004). Ensiklopedi Oxpord Dunia Islam Modern. Mizan, Bandung. Hal. 259-260

Hasan, D. (1996). Peranan Bank Dalam Pembangunan, Majalah Padjadjaran Jilid XXIV No. 2 hal 7.

Hermansyah, (2005). Hukum Perbankan Nasional Indonesia, Prenada Media, Jakarta.

Hilman. I. (2003). Dual Banking System: Perannya Dalam Membentuk Value of Firm. Majalah Percikan Iman, Oktober, hal. 68.

Karim, A. (2004). Bank Islam: Analisi Fiqih dan Keuangan (Ed.), Raja Grafindo Persada Jakarta .

Kusumaatmadja, M. (2002). Konsep-konsep Hukum dalam Pembangunan, Alumni, Bandung, 2002.

Cipta, Bandung, hal. 11

(tanpa tahun). Fungsi Hukum dalam Pembangunan. Bina (1995). Pemantapan Cita Hukum dan Asas-asa Hukum Nasional di Masa Yang Akan Datang, Majalah Hukum Nasional, BPHN, hal. 99 -100

Muhammad, (2007). Lembaga Ekonomi Syariah, Graha Ilmu, Cetakan Pertama, Yogyakarta, 2007.

Suhendi, H. (2007). Fiqih Muamalah (Membahas Ekonomi Islam, Kedudukan harta, Hak Milik, Jual Beli, Bunga Bank Dan Riba, Musyarakah, Ijarah, Mudayanah, Koperasi, Asuransi, Etika Bisnis dll.), Edisi 1-3, Raja Grafindo Persada, Jakarta,.

Setyobudi, A. (2007). Peran Serta Bank Indonesia dalam Pengembangan UMKM. Buletin Hukum Perbankan dan Kebanksentralan Vol. 5. No. 2 Agustus 2007. hal. 30 Sunggono, B. (1995). Pengantar Hukum Perbankan. Mandar Maju, Bandung. hal. 53

Venardos, A. M. (2005). Islamic Banking \& Finance In South-East Asia (Its Development \& Future), 2nd Edition, Fuisland Offset, Singapore.

Vogel, F. E. \& Hayes, S. L. (2007). III (Penterjemah: M. Sobirin Asnawi at. al.), Hukum Keuangan Islam, Konsep, Teori dan Praktek (Islamic Law and Finance: Religion, Risk, and Return), Cet. I, Nusamedia, Bandung, 2007. 


\section{Peraturan Perundang-undangan:}

UU No. 10 Tahun 1998 Ttg Perubahan Atas Undang-undang Nomor 7 Tahun 1992 Ttg Perbankan.

UU No. 3 Tahun 2004 Ttg Perubahan Atas Undang-undang Nomor 23 Tahun 1999 Ttg Bank Indonesia.

UU No. 20 Tahun 2008 Ttg Usaha Mikro, Kecil, dan Menengah.

UU No. 21 Tahun 2008 Ttg Perbankan Syariah.

UU No. 3 Ttg Amandemen Atas Undang-undang Nomor 7 Tahun 1989 Ttg Peradilan Agama

UU No. 50 Tahun 2008 Ttg Perubahan Kedua Atas Undang-undang Nomor 7 Tahun 1989 Ttg Peradilan Agama.

PERMA No. 2 Tahun 2008 Ttg Kompilasi Hukum Ekonomi Syariah (KHES).

\section{Sumber Internet}

http:// www.bi.go.id/utama/publikasi/upload. Blue Print Pengembangan Perbankan Syariah Nasional

http:// bi.@ go.id. „Bank Indonesia: Apa, Siapa, dan Bagaimana ?./2/10/2006.

http://tokohindonesia.com/ "Penerima Nobel Perdamaian 2006 M Yunus Pembebas Kaum Papa", 30/10/2009. 